\title{
Permission to quote from the following is gratefully acknowledged
}

John Donne: The Elegies and Songs and Sonnets, ed. Helen Gardner (Oxford: Clarendon Press, 1965). By permission of Clarendon Press.

The Poems and Letters of Andrew Marvell, 3d ed., edited by H. H. Margoliouth, revised by Pierre Legouis and E. E. Duncan-Jones (Oxford: Clarendon Press, 197I). By permission of Clarendon Press.

The Petrarch quotations are reprinted by permission of the publishers from Petrarch's Lyric Poems by Robert M. Durling (Cambridge, Mass.: Harvard University Press, 1976). Copyright (C) by Robert M. Durling.

Sir Thomas Wyatt: The Complete Poems, ed. R. A. Rebholz (New Haven: Yale University Press, 1978). By permission of Penguin Books.

A substantial portion of the chapter on Marvell's "Nymph complaining for the death of Her Faun" was first delivered to the eighth Biennial Renaissance Conference at the University of Michigan-Dearborn and subsequently printed in the selected proceedings of that conference, On the Celebrated and Neglected Poems of Andrew Marvell, ed. Claude J. Summers and Ted-Larry Pebworth (Columbia: University of Missouri Press, 1992). Part of the first chapter on Wyatt was read at the MLA Convention in Chicago in 1990 and published in Rethinking the Henrician Era, ed. Peter Herman (Urbana: University of Illinois Press, I994).

A very early version of the second Wyatt chapter appeared as "Becoming the Other / The Other Becoming: Transformation in Wyatt's Poetry," ELH 5 I (1984) : 43 I-45. Preliminary versions of the Donne chapters were published as "Baring the ' $\mathrm{l}$ ' and Bearing the 'You': Donne's Elegy, 'Change,' and 'A Valediction of My Name in the Window,' " Texas Studies in Literature and Language 30 (1988): 345-62; and "Donne's Injured 'I': Defections from Petrarchan and Spenserian Poetics," Philological Quarterly 66 (1987): 17593.

I am grateful to the editors of those articles for their help at the time of the original printing and for permission to reprint here. 

(5)

For Mark and Robin 
